Article

\title{
Nitrogen Sources Effect on Lactobacillus reuteri Growth and Performance Cultivated in Date Palm (Phoenix dactylifera L.) By-Products
}

\author{
Amira A. Ayad ${ }^{1, *(\mathbb{D}}$, Deiaa A. Gad El-Rab ${ }^{2}$, Salam A. Ibrahim ${ }^{3}{ }^{\mathbb{D}}$ and Leonard L. Williams ${ }^{1} \mathbb{C}$ \\ 1 Center for Excellence in Post-Harvest Technologies, The North Carolina Research Campus, North Carolina \\ A\&T State University, 500 Laureate Way, Kannapolis, NC 28081, USA; llw@ncat.edu \\ 2 Dairy Science Department, Food Industry and Nutrition Division, National Research Center, 33 El Buhouth \\ St. Ad Doqi, Cairo 12622, Egypt; deiaa73@gmail.com \\ 3 Food Microbiology and Biotechnology Laboratory, Food and Nutritional Science Program, North Carolina \\ Agricultural and Technical State University, Greensboro, NC 27411, USA; ibrah001@ncat.edu \\ * Correspondence: aaayad@ncat.edu; Tel.: +1-704-250-5703
}

Received: 27 May 2020; Accepted: 27 June 2020; Published: 30 June 2020

check for updates

\begin{abstract}
Lactic acid bacteria (LAB) are fastidious microorganisms that have specific nutritional requirements. The de Man, Rogosa, and Sharpe (MRS) is an expensive standard growth medium for LAB to produce lactic acid, and the industry is always looking for an alternative low-cost medium. The date palm (Phoenix dactylifera L.) is naturally full of essential nutrients that lead to stimulate or promote the growth of Lactobacillus spp. The date fruit industries generate a large amount of unwanted date by-product. Thus, the objective of this study was to examine the effect of different nitrogen sources on the growth of Lactobacillus reuteri grown in a date base medium. In this study, date palm fruit was pressed, and the fiber was blended with distilled water, centrifuged, and the supernatant was autoclaved to obtain date palm extract (DPE). The date palm medium (DPM) was formed by mixing the DPE with buffer solution. The DPM was then supplemented with different concentrations of different nitrogen sources. Lactobacilli MRS was used as a standard growth medium. Three different $L$. reuteri strains were individually inoculated into batches of MRS and DPMs at an initial inoculum 2.5 Log CFU/mL, and then incubated at $37^{\circ} \mathrm{C}$ for $18 \mathrm{~h}$. Bacterial growth was monitored by measuring the optical density readings (O.D $610 \mathrm{~nm}$ ) for up to $18 \mathrm{~h}$. At the end of the incubation period, final populations of each individual strain were verified by enumeration of the MRS agar. Our results showed that the bacterial population in DPM (control; without nitrogen), reached $3.55 \pm 0.5 \mathrm{Log} \mathrm{CFU} / \mathrm{mL}$. However, the bacterial populations that reached $7.03 \pm 0.1 \mathrm{Log} \mathrm{CFU} / \mathrm{mL}$ in the DPM medium were supplemented with $0.8 \%$ phytone peptone, compared to the MRS $7.90 \pm 0.24 \mathrm{Log} C F U / \mathrm{mL}$. Our findings thus suggest that date by-products could be used as a low-cost alternative for the LAB growth medium.
\end{abstract}

Keywords: culture growth; date palm by product; lactic acid bacteria; value-added products; nitrogen sources; phytone peptone

\section{Introduction}

Lactic acid bacteria (LAB) have been used significantly in various food applications such as meat, vegetables, beverages, dairy products, and other fermented products [1]. Depending upon the special nutritional requirements of LAB species, a large variety of culture media have been developed with different purposes and uses. Culture media must contain all the essential nutritional requirements of the bacterial culture's growth [2]. High cell mass productions have become constantly important 
as several companies have developed an interest in LAB not only as a starter culture, but also as a valuable probiotic additive to their food products $[3,4]$.

Lactic acid bacteria are demanding microorganisms that have complex nutritional requirements for growth, including nitrogen source. Lactobacilli strains primarily use peptides to fulfill their demand for complex nitrogen $[5,6]$. Guiying Zhang et.al. stated that peptides are required either to grow lactic acid bacteria, or to stimulate their development [7]. Therefore, peptides can be obtained from a number of sources, including skim milk, yeast extract, and because each source contains different peptides, each strain will respond differently to each source of protein due to the particularity of the enzymes involved [8]. However, these nitrogen sources are expensive and form a significant portion of media costs. The standard medium, the de Man, Rogosa, and Sharp (MRS), is the main medium used to grow LAB. The general composition of the growth medium consists of three groups: 1 . Carbon source (energy source), 2. Nitrogen source, and 3. Buffer solution. However, it is expensive, and the industry is always looking for an alternative low-cost medium. Many studies have suggested that Lactobacillus reuteri (L. reuteri) has a strong clinical record and strong probiotic properties, such as the ability to generate antimicrobial products and the ability to prevent and minimize hypercholesterolaemia in mice [9]. Therefore, three different species of L. reuteri (CF2-7F, DSM 20016, and 55730) were used in this study.

Therefore, the utilization of unused food and agricultural by-products could be suitable for the cultivation of Lactobacillus as an alternative medium at a low cost [10]. Food processing produces many by-products such as fruit pomace, seeds, peels, pulps, unused flesh, and husks. Although these by-products typically have been considered waste, studies have shown that these by-products can be promising sources of valuable components that have several functionalities [11]. Several studies have been conducted to replace expensive nitrogen sources with ingredients at a low cost. Agricultural by-products such as wheat bran hydrolysates combined with steep corn liquor [12], steep corn liquor mixed with Tween 80 , and $\mathrm{K}_{2} \mathrm{HPO}_{4}$ [13], canned molasses with marine and animal by-products [14], and sweet potato supplemented with yeast extract [15] have been tested. Consequently, fruit by-products such as palm dates are potentially good sources of energy, vitamins, and minerals that can boost or sustain LAB growth [16].

Date fruit (Phoenix dactylifera L.) has been identified as a highly nutritious food with many functional benefits to human health. Date fruit is nutrient-rich and includes carbohydrates (mainly sucrose, glucose, and fructose), fiber, vitamins, minerals, and proteins (Table 1) which are essential to stimulate or promote Lactobacillus spp. growth. Dates contain a high source of energy; it is approximated that $100 \mathrm{~g}$ of the flesh can provide $314 \mathrm{kcal}$ of energy [17]. Each year, the date fruit production process includes significant loss of fruit dates that occur during the methods of harvesting, processing, marketing, and handling; more than 55,000 tons of dates labeled as "by-products" [18-20] (Figure 1). Date fruit industries generate quantities of date by-products which have been discarded or used in very limited cases [21]. In our previous work [22], we tested the date by-products' ability to be used solely as a C-source. Therefore, in this paper, the objective was to extend our work by examining the effect of different nitrogen sources on the cell mass production of Lactobacillus reuteri grown in date by-products as a base medium.

Table 1. Dates (Phoenix dactylifera), Medjdoul, nutritional value per $100 \mathrm{~g}$.

\begin{tabular}{cc}
\hline Principle & Nutrient Value \\
\hline Energy & $307.12 \mathrm{Kcal}$ \\
\hline Carbohydrates & $74.97 \mathrm{~g}$ \\
\hline Protein & $1.81 \mathrm{~g}$ \\
\hline Total Fat & $0.15 \mathrm{~g}$ \\
\hline Dietary Fiber & $6.7 \mathrm{~g}$ \\
\hline
\end{tabular}


Table 1. Cont.

\begin{tabular}{ccc}
\hline \multirow{2}{*}{ Principle } & Nutrient Value \\
\hline \multirow{4}{*}{ Vitamins } & Folates & $0.015 \mathrm{mg}$ \\
\cline { 2 - 3 } & Niacin & $1.61 \mathrm{mg}$ \\
\cline { 2 - 3 } & Pantothenic acid & $0.805 \mathrm{mg}$ \\
\cline { 2 - 3 } & Pyridoxine & $0.249 \mathrm{mg}$ \\
\cline { 2 - 3 } & Riboflavin (B2) & $0.060 \mathrm{mg}$ \\
\cline { 2 - 3 } & Thiamin (B1) & $0.050 \mathrm{mg}$ \\
\cline { 2 - 3 } & Vitamin A & $0.16 \mathrm{mg}$ \\
\hline \multirow{4}{*}{ Minerals } & Vitamin K & $0.0027 \mathrm{mg}$ \\
\cline { 2 - 3 } & Calcium & $64 \mathrm{mg}$ \\
\cline { 2 - 3 } & Copper & $0.36 \mathrm{mg}$ \\
\cline { 2 - 3 } & Iron & $0.90 \mathrm{mg}$ \\
\cline { 2 - 3 } & Magnesium & $54 \mathrm{mg}$ \\
\cline { 2 - 3 } & Manganese & $0.296 \mathrm{mg}$ \\
\cline { 2 - 3 } & Phosphorus & $62 \mathrm{mg}$ \\
\cline { 2 - 3 } & Zinc & $0.44 \mathrm{mg}$ \\
\hline
\end{tabular}

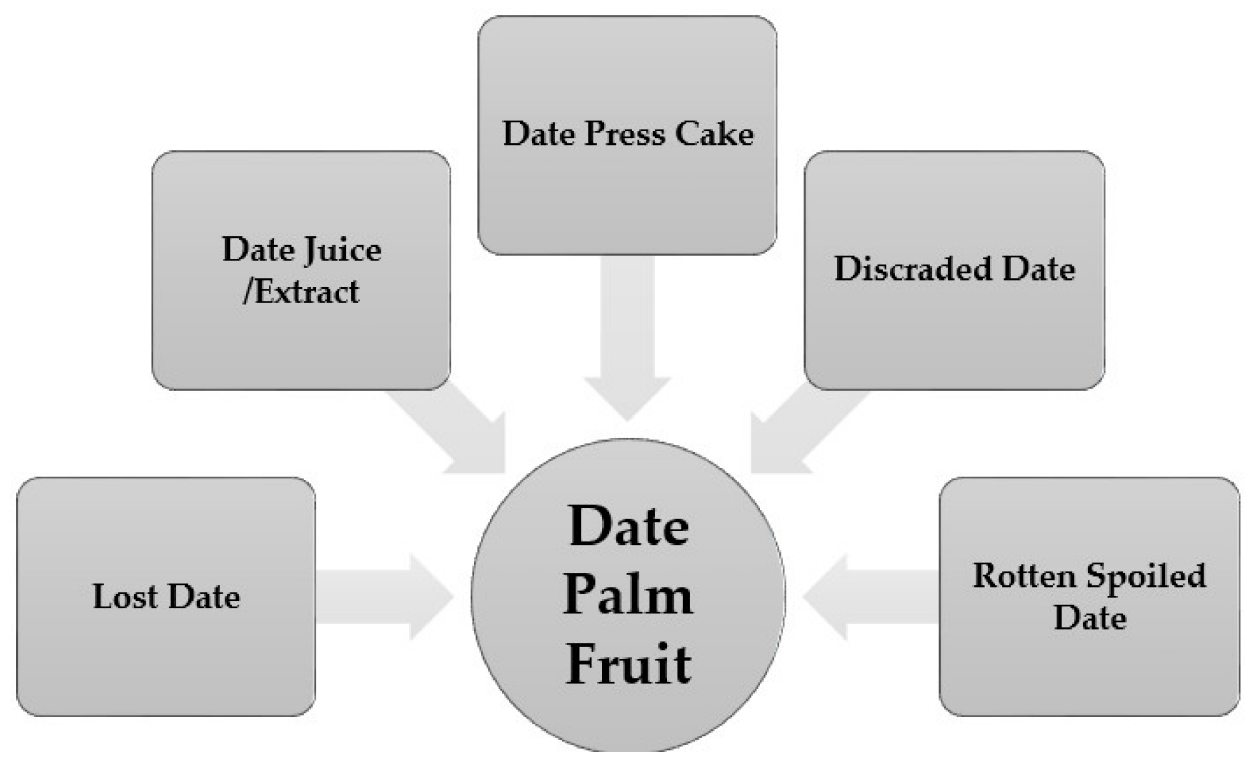

Figure 1. Date palm fruit by-products and wastes.

\section{Materials and Methods}

\subsection{Date Extract Formulation}

Date palm extract was obtained by following the protocol as per Ayad et. al., [22] with slight modifications. The date palm fruit was freshly picked from nearby Greensboro, NC store. The date palm fleshes were pressed for 10 days to ooze out the syrup. The date fiber was blended with distilled water at a ratio of $1: 2(\mathrm{w} / \mathrm{v})$. The mixture was heated inside a shaking water bath at $65^{\circ} \mathrm{C}$ for $2 \mathrm{~h}$. The solution was blended for $5 \mathrm{~min}$, and then centrifuged at $4696 \mathrm{xg}$ for $25 \mathrm{~min}$ at $4{ }^{\circ} \mathrm{C}$. The collected supernatant (1 L) labeled as date extract (DPE) was autoclaved at $110^{\circ} \mathrm{C}$ for $15 \mathrm{~min}$. Date palm medium (DPM) was combined with a mixture of DPE and buffer solution (BS) at a ratio of 2:3 (v/v). The DPM was dispensed in a sterile $200 \mathrm{~mL}$ bottle for experimental work. 


\subsection{Preparation of Buffer Solution (BS)}

By dissolving the following chemicals: $(1 \mathrm{~g}) \mathrm{L}-\mathrm{Cysteine.} \mathrm{HCL},(2 \mathrm{~g})$ disodium phosphate $\mathrm{Na}_{2} \mathrm{HPO}_{4}$, (2 g) ammonium citrate $\mathrm{NH}_{4} \mathrm{C}_{6} \mathrm{H}_{5} \mathrm{O}_{7},(5 \mathrm{~g})$ Sodium acetate $\mathrm{C}_{2} \mathrm{H}_{3} \mathrm{NaO}_{2},(0.15 \mathrm{~g})$ Calcium chloride $\mathrm{CaCl}_{2}$, (2 g) Dipotassium phosphate $\mathrm{K}_{2} \mathrm{HPO}_{4},(0.2 \mathrm{~g}) \mathrm{MgSO}_{4} .7 \mathrm{H}_{2} \mathrm{O},(0.05 \mathrm{~g}) \mathrm{MnSO}_{4} .5 \mathrm{H}_{2} \mathrm{O}$, and (1 mL) Tween 80 in $1 \mathrm{~L}$ of distilled water, the buffer solution (BS) $(1 \mathrm{~L})$ was developed. The mixture was sterilized at $121{ }^{\circ} \mathrm{C}$ for $15 \mathrm{~min}$.

\subsection{Preparation of Protein Source}

Four different nitrogen sources were used in this study (see Table 2). Batches of $100 \mathrm{ml}$ of DPM with different concentrations $(0 \%, 0.2 \%, 0.4 \%, 0.6 \%$, and $0.8 \%, \mathrm{w} / \mathrm{v})$ of each of the nitrogen sources were prepared.

Table 2. Chemical Description of Protein Sources Used in This Study.

\begin{tabular}{ccc}
\hline Source & Description/Application & Suppliers \\
\hline Peptone (PI) & $\begin{array}{c}\text { Enzymatic digest of animal tissue, nitrogen } \\
\text { in a form readily available to bacteria }\end{array}$ & Fisher Sci. \\
\hline Tryptone (PII) & $\begin{array}{c}\text { Pancreatic digest of casein is used as a } \\
\text { nitrogen source for bacteria }\end{array}$ & Fisher Sci. \\
\hline Proteose peptone No.3 (PIII) & Enzymatic digest of protein & BD Difco \\
\hline Phytone peptone (PIV) & $\begin{array}{c}\text { Papaic digest of soybean meal, designed } \\
\text { specifically for cell culture applications, } \\
\text { non-animal origin }\end{array}$ & BD Difco \\
\hline
\end{tabular}

\subsection{Preparation of $M R S$}

Lactobacilli MRS broth was prepared based on the formulations of de Man, Rogosa, and Sharpe (MRS). MRS broth was sterilized at $121^{\circ} \mathrm{C}$ for $15 \mathrm{~min}$, cooled down, and then stored in a refrigerator to be used within two days.

\subsection{Bacterial Culture Activation}

Three strains of Lactobacillus reuteri ATCC (PTA-4965, 23272, and 55730) were obtained from the $\left(-80^{\circ} \mathrm{C}\right)$ stock storage collections of the Food Microbiology and Biotechnology Laboratory at North Carolina Agricultural and Technical States University. A total of $10 \mathrm{~mL}$ of fresh MRS broth was inoculated with $(100 \mu \mathrm{L})$ of each culture, then incubated at $37^{\circ} \mathrm{C}$ for $24 \mathrm{~h}$. Cultures were streaked on MRS agar and incubated at $37^{\circ} \mathrm{C}$ for $48 \mathrm{~h}$ for experimental work.

\subsection{Adaption Procedure}

The overnight grown cultures were individually sub-cultivated twice in $10 \mathrm{~mL}$ batches of DPM and MRS broth then incubated overnight at $37^{\circ} \mathrm{C}$. The activated strains were extracted through centrifugation at $4696 \mathrm{xg}$ for $10 \mathrm{~min}$ at $4{ }^{\circ} \mathrm{C}$ and then double washed with phosphate-buffered saline (PBS), (1x, pH 6.8).

\subsection{Inoculation Procedure}

Each strain of L. reuteri (PTA-4965, 23272, and 55730) was tenfold serially diluted (up to $10^{-9}$ ) in PBS. Then $100 \mu \mathrm{L}(\sim 3.1 \mathrm{Log}$ CFU/mL) was inoculated to each batch of DPMs and MRS broth and mixed thoroughly. Each batch was incubated at $37^{\circ} \mathrm{C}$ for $24 \mathrm{~h}$. Initial bacterial populations were determined using the bacterial enumeration method. 


\subsection{Determination of Bacterial Growth, Titratable Acidity, and Changing $p H$ Values}

Bacterial growth was monitored during the incubation period at $37^{\circ} \mathrm{C}$ by measuring turbidity (O.D $610 \mathrm{~nm}$ ), titratable acidity (TA), and $\mathrm{pH}$ values. Turbidity was monitored by measuring the optical density (O.D $610 \mathrm{~nm}$ ) readings using a Thermo Scientific Genesys 10S UV-Vis spectrophotometer (Thermo Fisher Scientific, Madison, WI) at $2 \mathrm{~h}$ intervals for $18 \mathrm{~h}$. The TA was determined by titrating with $0.1 \mathrm{~N} \mathrm{NaOH}$ using a $\mathrm{pH}$ meter and calculated as a percentage of acid. The $\mathrm{pH}$ values of each sample were measured at the beginning $(0 \mathrm{~h})$ and end $(18 \mathrm{~h})$ of the fermentation period. The $\mathrm{pH}$ meter (Accumet Basic, AB15/15+, Fisher Scientific, Pittsburgh, PA) was calibrated with pH standard buffers 4.0 and 7.0. After calibration, sample $\mathrm{pH}$ was taken and recorded. The electrode was rinsed with distilled water between different samples.

\subsection{Bacterial Enumeration}

The microbial populations (Log CFU/mL) were calculated by plating on the MRS agar. The $(1 \mathrm{~mL})$ samples were severely diluted in $9 \mathrm{~mL}$ of PBS, and then $100 \mu \mathrm{L}$ from the appropriated dilution was subsequently surface plated on MRS plates in triplicate. Plates were anaerobically incubated for $48 \mathrm{~h}$ at $37^{\circ} \mathrm{C}$. Plates with 25-250 colonies were counted, and the bacterial population was translated to $\log \mathrm{CFU} / \mathrm{mL}$.

\subsection{Statistical Analysis}

Each experiment was repeated three times, independently. All analyses and enumerations have been made in duplicate. The mean square of each treatment was calculated. Significant differences $(p<0.05)$ between treatments were observed using Duncan's multiple range test. The one-way variance analysis (ANOVA) was conducted using SAS (9.4) to determine significant effects at a $p<0.05$ significance level.

\section{Results}

In our study, the effects of supplementing date palm extract (DPE) with different nitrogen sources (PI, PII, PIII, and PIV) at different concentrations $(0.0 \%, 0.2 \%, 0.4 \%, 0.6 \%$, and $0.8 \%, w / v)$ were examined. Figure 2 shows the growth of the L. reuteri 55730 strain in MRS and DPM broth. Growth was monitored by measuring the optical density (O.D. $610 \mathrm{~nm}$ ). In the medium of MRS, the O.D. 610 attained an average of 0.813 within $8 \mathrm{~h}$. There was no visual growth when the same strain was cultivated in the DPM without protein supplementation (control). However, when $0.2 \%$ of PI, PII, PIII, and PIV was added to DPM, the bacterial strain grew, reaching an O.D. 610 of 0.32, 0.31, 0.33, and 0.35, respectively. With the addition of $0.4 \%$ of PI, PII, PIII, and PIV, the O.D. 610 reached $0.44,0.45,0.41$, and 0.49 , respectively. Similarly, when DPM was supplemented with $0.6 \%$ of PI, PII, PIII, and PIV, the O.D. 610 reached $0.65,0.57,0.61$, and 0.62 , respectively. Upon additional supplementation at $0.8 \%$, the O.D. 610 reached $0.71,0.72,0.73$, and 0.78 , respectively. Our results indicated that phytone peptone (PIV) had a higher bacterial growth compared to other sources of proteins. To confirm the effect of protein sources on a bacterial population, additional work was conducted to measure the final population in each treatment. Table 3 shows the bacterial populations (Log CFU/mL) of the L. reuteri 55730 strain at $37^{\circ} \mathrm{C}$ after $18 \mathrm{~h}$ of incubation. The bacterial population only exceeded $3.38 \mathrm{Log}$ CFU/mL from an initial population of approximately $2.44 \mathrm{Log} C F U / \mathrm{mL}$ when the strain was grown in the DPM control. When DPM was supplemented with $0.2 \%$ of PI, PII, PIII, and PIV, the population reached 3.52, 2.40, 3.57, and 4.68 Log CFU/mL, respectively. With the addition of $0.4 \%$ of PI, PII, PIII, and PIV, the bacterial population reached 4.71, 4.73, 4.73, and 4.73 Log CFU/mL, respectively. Similarly, when DPM was supplemented with $0.6 \%$ of PI, PII, PIII, and PIV, the population of the strain L. reuteri 23272 reached 6.6, 6.64, 6.58, and 6.78 Log CFU/mL, respectively. However, when DPM was supplemented with $0.8 \%$ PI, PII, PIII, and PIV, the population of L. reuteri 23272 reached 6.78, 6.79, 6.72, and $6.93 \mathrm{Log} \mathrm{CFU} / \mathrm{mL}$, respectively. However, the bacterial populations from the initial population 
2.56 Log CFU/mL continued to grow in the MRS sample and on average reached 7.86 Log CFU/mL. Our results demonstrated that phytone peptone (PIV) provided bacterial cells with enough nutrients to reach a higher bacterial population compared to other sources of proteins. Figures 3 and 4 show that a similar pattern of growth was detected with the L. reuteri 23272 and PTA4965 strains. Our results demonstrated that the growth of L. reuteri depends on the phytone peptone (PIV) concentration, not on the strain. Analogous growth patterns results were obtained with the L. reuteri 23272 and PTA4965 strains which are shown in Tables 4 and 5, respectively. These results confirmed that the growth of L. reuteri strains depend on the phytone peptone concentration.
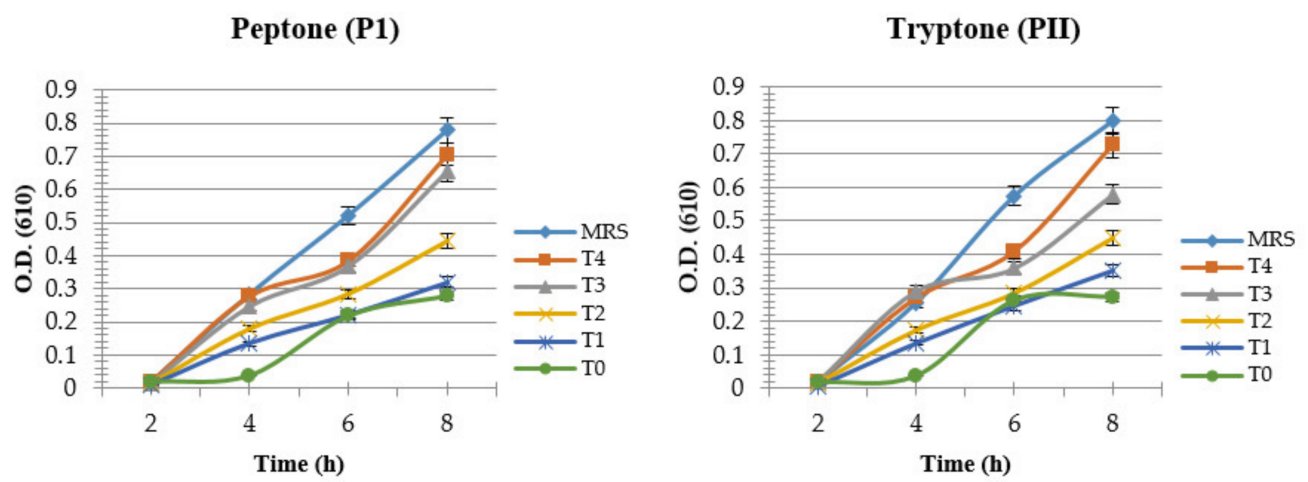

Proteose Peptone \#3 (PIII)
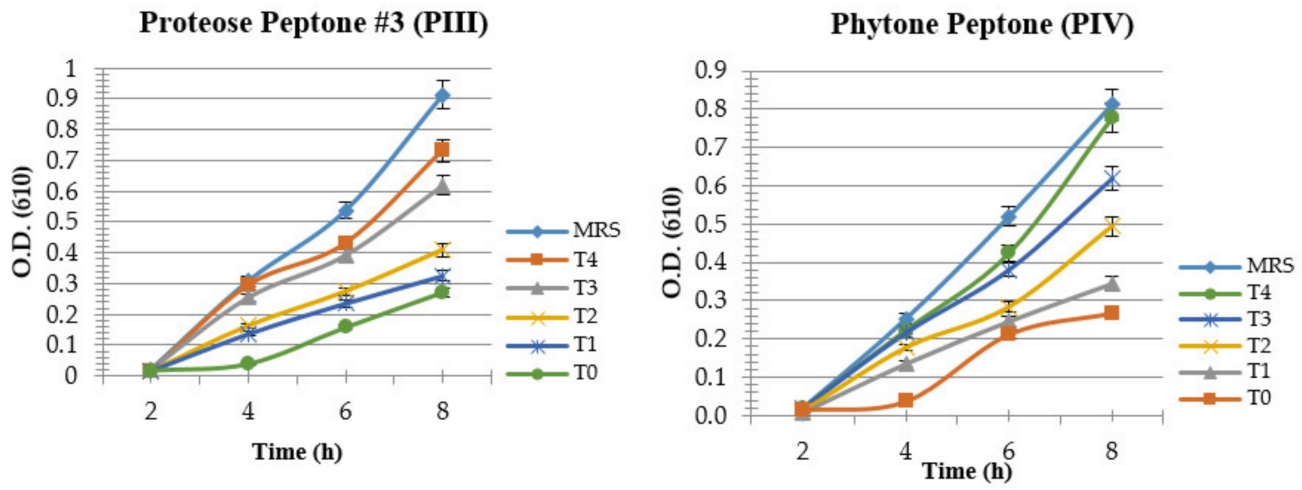

Figure 2. Growth of L. reuteri 55730 during incubation at $37^{\circ} \mathrm{C}$ for $8 \mathrm{~h}$ in MRS and DPM as measured by the optical density at $610 \mathrm{~nm}$. T0 $=$ control, $\mathrm{T} 1=0.2 \%, \mathrm{~T} 2=0.4 \%, \mathrm{~T} 3=0.6 \%, \mathrm{~T} 4=0.8 \%$ of protein source; PIV = Phytone Peptone, PIII = Proteose peptone No. 3, PII = Tryptone, PI= Peptone.

Table 3. Culture Populations Log CFU/mL of L. reuteri 55730 during incubation at $37^{\circ} \mathrm{C}$ for $18 \mathrm{~h}$ in de Man, Rogosa, and Sharpe (MRS) and date palm medium (DPM).

\begin{tabular}{ccccc}
\hline & \multicolumn{4}{c}{ Protein Source } \\
\hline Growth Medium & PIV & PIII & PII & PI \\
\hline DPM+0.0\% (control) & \multicolumn{4}{c}{$3.46 \pm 0.1^{\mathrm{E}}$} \\
\hline $\mathrm{DPM}+0.2^{\mathrm{E}} \%$ & $3.45 \pm 0.0^{\mathrm{E}}$ & $3.51 \pm 0.0^{\mathrm{E}}$ & $3.35 \pm 0.0^{\mathrm{E}}$ & $3.42 \pm 0.0^{\mathrm{E}}$ \\
\hline $\mathrm{DPM}+0.4 \%$ & $4.74 \pm 0.0^{\mathrm{D}}$ & $4.74 \pm 0.0^{\mathrm{C}}$ & $4.67 \pm 0.0^{\mathrm{C}}$ & $4.61 \pm 0.0^{\mathrm{D}}$ \\
\hline $\mathrm{DPM}+0.6^{\mathrm{C}} \%$ & $6.79 \pm 0.0^{\mathrm{C}}$ & $5.64 \pm 0.0^{\mathrm{B}}$ & $5.78 \pm 0.0^{\mathrm{B}}$ & $5.27 \pm 0.0^{\mathrm{C}}$ \\
\hline $\mathrm{DPM}+0.8 \%$ & $7.04 \pm 0.0^{\mathrm{B}}$ & $6.64 \pm 0.0^{\mathrm{B}}$ & $6.72 \pm 0.0^{\mathrm{B}}$ & $6.86 \pm 0.0^{\mathrm{B}}$ \\
\hline
\end{tabular}

Note. PIV = Phytone peptone; PIII = Proteose peptone No. 3; PII = Tryptone; PI = Peptone; MRS (standard) reached average to $7.86 \mathrm{Log} \mathrm{CFU} / \mathrm{mL}$; initial inoculum level was approximately $2.5 \mathrm{Log} \mathrm{CFU} / \mathrm{mL}$; mean values in the same columns with the same superscript are not significantly different at $p<0.05$, values are $\mathrm{M} \pm \operatorname{SD}(n=3)$. 

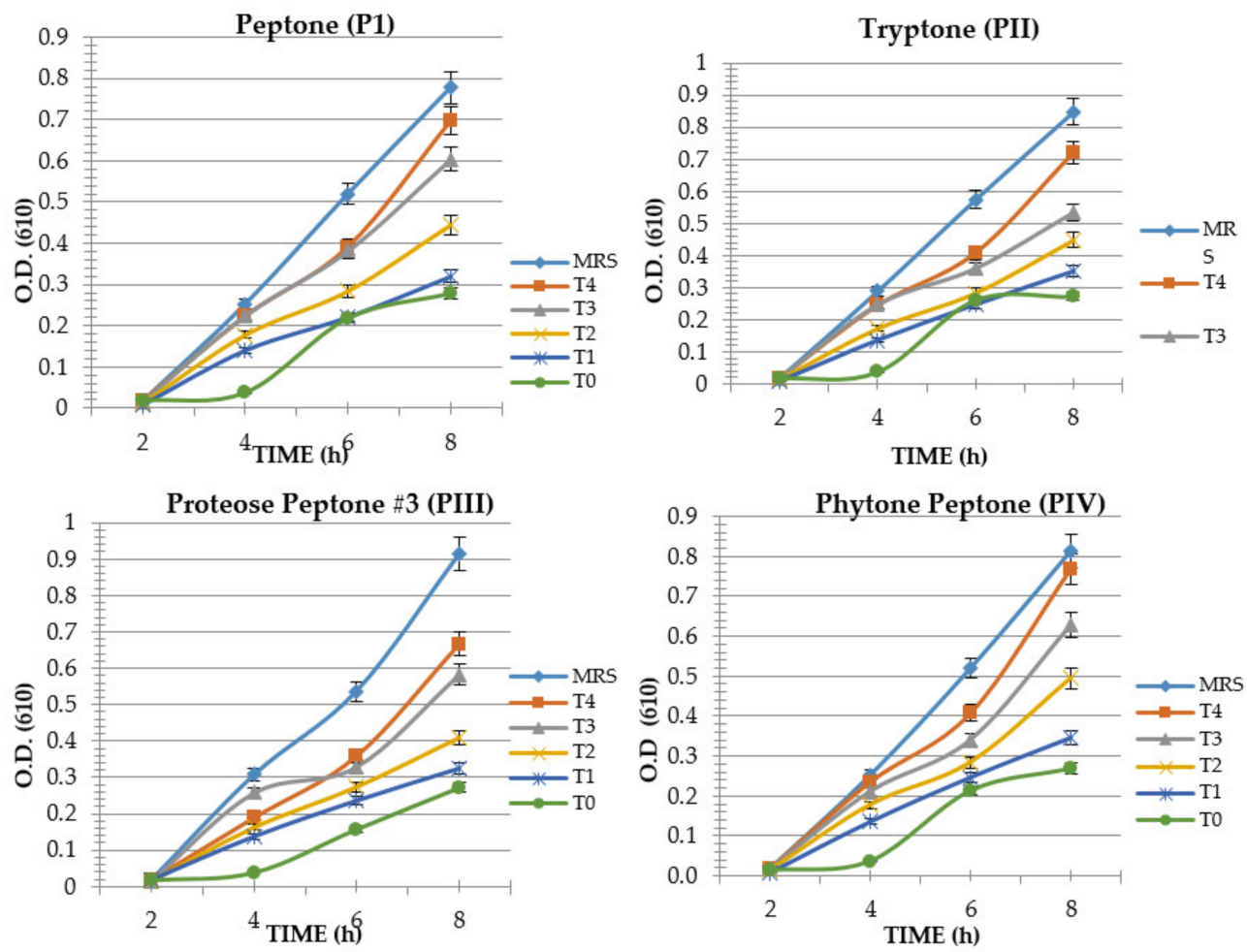

Figure 3. Growth of L. reuteri 23272 during incubation at $37^{\circ} \mathrm{C}$ for $8 \mathrm{~h}$ in MRS and DPM as measured by the optical density at $610 \mathrm{~nm}$. T0 $=$ control, $\mathrm{T} 1=0.2 \%, \mathrm{~T} 2=0.4 \%, \mathrm{~T} 3=0.6 \%, \mathrm{~T} 4=0.8 \%$ of protein source.
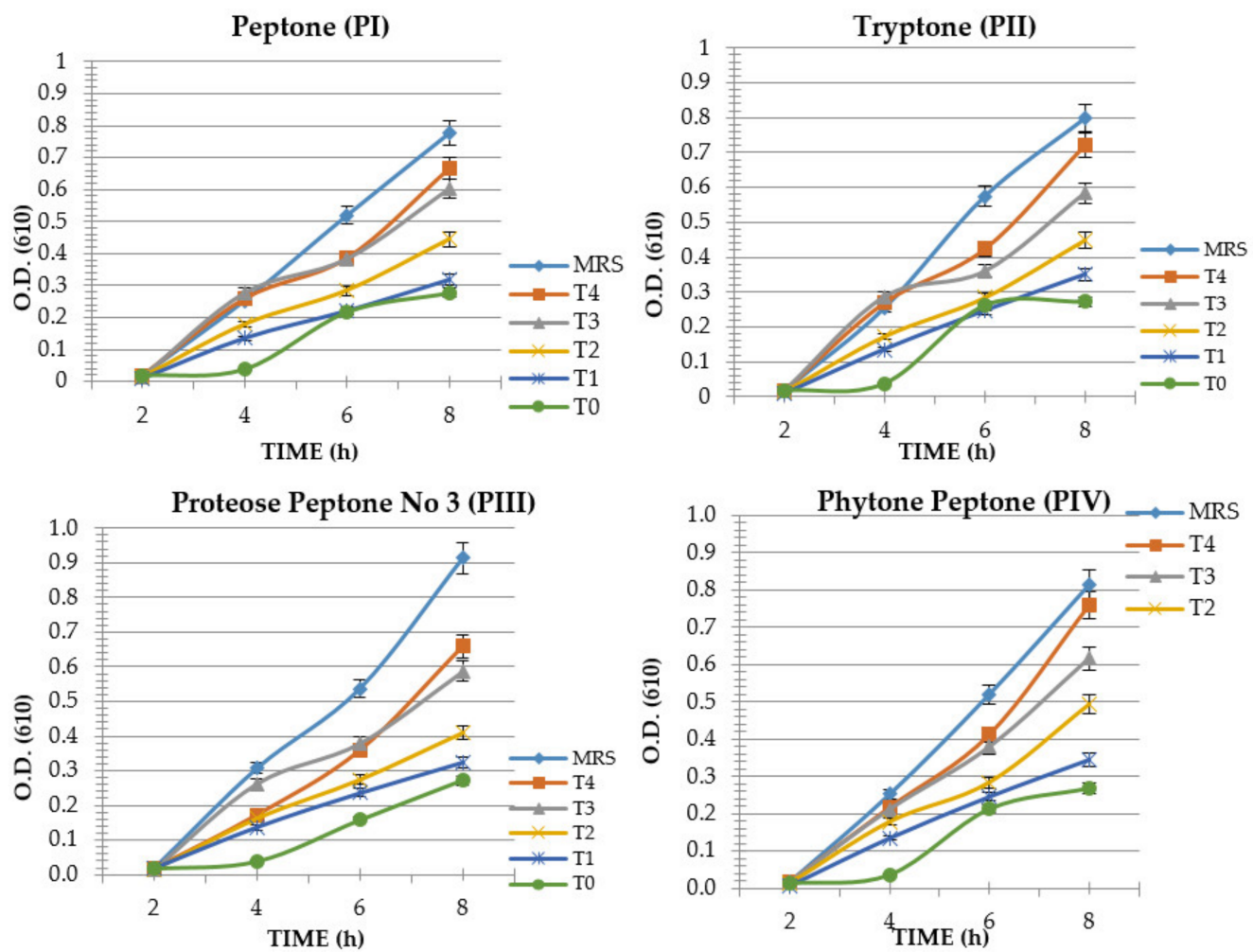

Figure 4. Growth of L. reuteri PTA4965 during incubation at $37{ }^{\circ} \mathrm{C}$ for $8 \mathrm{~h}$ in MRS and DPM as measured by the optical density at $610 \mathrm{~nm}$. T0 $=$ control, $\mathrm{T} 1=0.2 \%, \mathrm{~T} 2=0.4 \%, \mathrm{~T} 3=0.6 \%, \mathrm{~T} 4=0.8 \%$ of protein source. 
Table 4. Culture Populations Log CFU/mL of L. reuteri 23272 during incubation at $37^{\circ} \mathrm{C}$ for $18 \mathrm{~h}$ in MRS and DPM.

\begin{tabular}{ccccc}
\hline & \multicolumn{4}{c}{ Protein Source } \\
\hline Growth Medium & PIV & PIII & PII & PI \\
\hline DPM+0.0\% (control) & \multicolumn{4}{c}{$3.54 \pm 0.1^{\mathrm{D}}$} \\
\hline $\mathrm{DPM}+0.2^{\circ} \%$ & $3.72 \pm 0.0^{\mathrm{C}}$ & $3.53 \pm 0.0^{\mathrm{E}}$ & $3.51 \pm 0.1^{\mathrm{E}}$ & $3.52 \pm 0.0^{\mathrm{E}}$ \\
\hline $\mathrm{DPM}+0.4^{\mathrm{C}} \%$ & $4.72 \pm 0.1^{\mathrm{C}}$ & $4.68 \pm 0.1^{\mathrm{D}}$ & $4.67 \pm 0.1^{\mathrm{D}}$ & $4.71 \pm 0.1^{\mathrm{D}}$ \\
\hline $\mathrm{DPM}+0.6 \%$ & $6.83 \pm 0.0^{\mathrm{B}}$ & $6.58 \pm 0.0^{\mathrm{C}}$ & $5.48 \pm 0.0^{\mathrm{C}}$ & $6.78 \pm 0.0^{\mathrm{C}}$ \\
\hline $\mathrm{DPM}+0.8^{\mathrm{C}} \%$ & $7.14 \pm 0.0^{\mathrm{B}}$ & $6.92 \pm 0.0^{\mathrm{B}}$ & $6.79 \pm 0.1^{\mathrm{B}}$ & $7.00 \pm 0.0^{\mathrm{B}}$ \\
\hline
\end{tabular}

Note. PIV = Phytone peptone, PIII = Proteose peptone No. 3, PII = Tryptone, PI = Peptone; MRS (standard) reached average to $7.86 \mathrm{Log}$ CFU $/ \mathrm{mL}$; initial inoculum level was approximately $2.5 \mathrm{Log} \mathrm{CFU} / \mathrm{mL}$; mean values in the same columns with the same superscript are not significantly different at $p<0.05$, values are $\mathrm{M} \pm \mathrm{SD}(n=3)$.

Table 5. Culture Populations Log CFU/mL of L. reuteri PTA4965 during incubation at $37^{\circ} \mathrm{C}$ for $18 \mathrm{~h}$ in MRS and DPM.

\begin{tabular}{ccccc}
\hline & \multicolumn{4}{c}{ Protein Source } \\
\hline Growth Medium & PIV & PIII & PII & PI \\
\hline DPM+0.0\% (control) & \multicolumn{4}{c}{$3.55 \pm 0.1^{\mathrm{E}}$} \\
\hline $\mathrm{DPM}+0.2^{\circ} \%$ & $3.48 \pm 0.0^{\mathrm{D}}$ & $3.57 \pm 0.0^{\mathrm{E}}$ & $4.51 \pm 0.1^{\mathrm{D}}$ & $3.52 \pm 0.0^{\mathrm{E}}$ \\
\hline $\mathrm{DPM}+0.4 \%$ & $4.72 \pm 0.1^{\mathrm{D}}$ & $4.23 \pm 0.1^{\mathrm{D}}$ & $4.73 \pm 0.1^{\mathrm{C}}$ & $4.71 \pm 0.1^{\mathrm{D}}$ \\
\hline $\mathrm{DPM}+0.6 \%$ & $6.78 \pm 0.0^{\mathrm{C}}$ & $6.58 \pm 0.0^{\mathrm{C}}$ & $5.64 \pm 0.0^{\mathrm{B}}$ & $5.6 \pm 0.0^{\mathrm{C}}$ \\
\hline $\mathrm{DPM}+0.8 \%$ & $6.96 \pm 0.0^{\mathrm{B}}$ & $6.72 \pm 0.0^{\mathrm{B}}$ & $6.84 \pm 0.1^{\mathrm{B}}$ & $6.78 \pm 0.0^{\mathrm{B}}$ \\
\hline
\end{tabular}

Note. PIV = Phytone peptone, PIII = Proteose peptone No.3, PII = Tryptone, PI = Peptone; MRS (standard) reached average to $7.86 \mathrm{Log}$ CFU $/ \mathrm{mL}$; initial inoculum level was approximately $2.5 \mathrm{Log}$ CFU $/ \mathrm{mL}$; mean values in the same columns with the same superscript are not significantly different at $p<0.05$, values are $\mathrm{M} \pm \mathrm{SD}(n=3)$.

\section{Discussion}

Our results are consistent with other findings that date palm extract could support lactobacilli growth [23]. Our results indicated that supplementing date palm extract with different nitrogen sources increased the growth of Lactobacillus reuteri. Many studies suggested that Lactobacillus reuteri (L. reuteri) has a strong clinical record and strong probiotic properties, such as the ability to generate antimicrobial products $[24,25]$. Others have investigated the potential of the L. reuteri strain to utilize different protein sources to produce galactosidases [9].

Our results also agree with the work of Atilola et al., 2015 that the Phytone peptone (PIV) showed the best enhancing effect to support the growth of L. reuteri. Their results indicated that phytone peptone was promoting the growth of L. reuteri spp. by an average of $1.4 \log \mathrm{CFU} / \mathrm{mL}$ relative to their control group [8].

Dates have a wide range of nutritional functional components, and they are a good source of rapid energy due to their high carbohydrate content (70\%-80\%). Our findings indicated that DPM supplemented with PIV assisted the $L$. reuteri growth compared with the un-supplemented DPM (control). These results showed that no significant difference $(p>0.05)$ was observed in the growth of LAB in MRS and the developed DPM medium. These results demonstrated that DPM + 0.8 PIV could be a suitable medium for the growth of LAB and thus could be used as an alternative low-cost medium. Additionally, we calculated the estimation cost of adding the $0.8 \%$ of phytone peptone to the date by-product base medium (see Table 6).

To the best of our knowledge, this is the first study to report on the use of date palm by-products in the cultivation of LAB. Based on our findings, we have some limitations. The first limitation of our study is that we only used one date palm by-product species. Other kinds of date palm by-products 
could be tested in upcoming research. Additionally, we examined one extraction method for date palm by-products; in future research, other methods of extraction or other methods such as protein expression or enzyme activity could be performed. Another limitation could be that we studied specific probiotic microorganisms (Lactobacillus reuteri CF2-7F, DSM 20016, and 55730). Other LAB strains such as (Lactobacillus delbrueckii ssp. Bulgaricus and Bifidobacterium) could be examined.

Table 6. The total estimated cost of nitrogen sources for forming 1 Liter of DPM according to purchases made from BD Biosciences.

\begin{tabular}{cccc}
\hline \multirow{2}{*}{ Media } & Nitrogen Sources g/L & Cost per Gram & \multicolumn{2}{c}{$\begin{array}{c}\text { Total Cost of Nitrogen } \\
\text { Sources per Liter of Media }\end{array}$} \\
\hline \multirow{2}{*}{ MRS } & Proteose peptone No. 3 $(10 \mathrm{~g})$ & $\$ 0.467 / \mathrm{g}$ & $\$ 4.67$ \\
\cline { 2 - 4 } & Beef Extract $(10 \mathrm{~g})$ & $\$ 0.358 / \mathrm{g}$ & $\$ 3.58$ \\
\cline { 2 - 4 } & Yeast extract $(5 \mathrm{~g})$ & $\$ 0.194 / \mathrm{g}$ & $\$ 1.94$ \\
\hline DPM & Phytone peptone $(8 \mathrm{~g})$ & $\$ 0.186 / \mathrm{g}$ & Total $\$ 10.19$ \\
\hline
\end{tabular}

\section{Conclusions}

Our results revealed that DPM could be a suitable medium for the growth of LAB. Additionally, DPM could be used as a growth medium for the cultivation of Lactobacillus reuteri. This study demonstrated that the growth of LAB was improved by supplementing DPM with phytone peptone (PIV). The growth of the tested Lactobacillus strains in DPM+ 0.8\% PIV was similar to that in MRS. Therefore, DPM+ 0.8\% PIV can serve as an alternative medium to costly MRS broth. These findings might lead to more interesting applications of date palm by-products in lactic acid fermentation.

Author Contributions: Methodology, investigation, and writing-original draft preparation, A.A.A.; validation, and supervision D.A.G.E.-R.; supervision, funding acquisition-review, and editing, S.A.I.; writing-review, editing, and funding acquisition, L.L.W. All authors have read and agreed to the published version of the manuscript.

Funding: The project received funding from the National Food and Agriculture Institute of the USDA, project no. NC Hatch X-234-5-09-170-1. This work was funded in the Agricultural Research Program at North Carolina's Agricultural and State University.

Conflicts of Interest: The authors declare no conflict of interest.

\section{References}

1. Ayad, A.A.; El-Rab, D.G.; El-Kherbawy, G.; Zaki, S.; Williams, L. Stimulating the Viability of Bifidobacterium spp. in Synbiotic Fermented Milk by Co-culturing with Lactobacillus paracasei 441 and Inulin. Int. J. Hortic. Agric. Food Sci. 2018, 2, 174-181. [CrossRef]

2. Hébert, E.M.; Raya, R.R.; de Giori, G.S. Evaluation of Minimal Nutritional Requirements of Lactic acid Bacteria Used in Functional Foods, in Environmental Microbiology; Springer: Berlin, Germany, 2004; pp. 139-148.

3. Ibrahim, G.; Mehanna, N.S.; El-Rab, D.G.; Abd-El-Salam, M.; Kholif, A.; Abdou, S.; El-Shibiny, S. Preparation and properties of set fermented milk containing inulin and different probiotics. In Proceedings of the 9 th Egyptian Conference Dairy Science Technology, Cairo, Egypt, 9-11 October 2004; Egyptian Society of Dairy Science: Cairo, Egypt; pp. 117-132.

4. Barakat, O.S.; Ibrahim, G.; Tawfik, N.; El-Kholy, W.; El-Rab, G.D. Identification and Probiotic Characteristics of Lactobacillus strains Isolated from Traditional Domiati Cheese. Int. J. Microbiol. Res. 2011, 3, 59-66. Available online: http://www.bioinfo.in/contents.php?id=27 (accessed on 27 May 2020).

5. Lahtinen, S.; Ouwehand, A.C.; Salminen, S.; von Wright, A. Lactic Acid Bacteria: Microbiological and Functional Aspects; CRC Press: New York, NY, USA, 2011.

6. Liu, M.; Bayjanov, J.R.; Renckens, B.; Nauta, A.; Siezen, R.J. The Proteolytic System of Lactic Acid Bacteria Revisited: A Genomic Comparison. BMC Genom. 2010, 11, 36. [CrossRef] 
7. Zhang, G.; Mills, D.A.; Block, D.E. Development of chemically defined media supporting high-cell-density growth of lactococci, enterococci, and streptococci. Appl. Environ. Microbiol. 2009, 75, 1080-1087. [CrossRef] [PubMed]

8. Atilola, O.A.; Gyawali, R.; Aljaloud, S.O.; Ibrahim, S.A. Use of Phytone Peptone to Optimize Growth and Cell Density of Lactobacillus reuteri. Foods 2015, 4, 318-327. [CrossRef] [PubMed]

9. Gomaa, E.Z. $\beta$-galactosidase from Lactobacillus delbrueckii and Lactobacillus reuteri: Optimization, characterization and formation of galactooligosaccharides. Ind. J. Biotechnol. 2018, 17, 407-415.

10. Cotter, P.D.; Hill, C. Surviving the acid test: Responses of gram-positive bacteria to low pH. Microbiol. Mol. Biol. Rev. 2003, 67, 429-453. Available online: https://mmbr.asm.org/content/67/3/429.short (accessed on 27 May 2020). [CrossRef]

11. Gao, C.; Ma, C.; Xu, P. Biotechnological routes based on lactic acid production from biomass. Biotechnol. Adv. 2011, 29, 930-939. [CrossRef] [PubMed]

12. Li, Z.; Han, L.; Ji, Y.; Wang, X.; Tan, T. Fermentative production of L-lactic acid from hydrolysate of wheat bran by Lactobacillus rhamnosus. Biochem. Eng. J. 2010, 49, 138-142. [CrossRef]

13. Coelho, F.; Augusto, M.; Lages, L.F. Contextual factors and the creativity of frontline employees: The mediating effects of role stress and intrinsic motivation. J. Retail. 2011, 87, 31-45. Available online: http://isiarticles.com/ bundles/Article/pre/pdf/2248.pdf (accessed on 27 May 2020). [CrossRef]

14. Khannous, L.; Souissi, N.; Ghorbel, B.; Jarboui, R.; Kallel, M.; Nasri, M.; Gharsallah, N. Treatment of saline wastewaters from marine-products processing factories by activated sludge reactor. Environ. Technol. 2003, 24, 1261-1268. [CrossRef]

15. Hayek, S.A.; Shahbazi, A.; Awaisheh, S.S.; Shah, N.P.; Ibrahim, S.A. Sweet potatoes as a basic component in developing a medium for the cultivation of lactobacilli. Biosci. Biotechnol. Biochem. 2013, 77, 2248-2254. [CrossRef] [PubMed]

16. Tang, Z.X.; Shi, L.E.; Aleid, S.M. Date fruit: Chemical composition, nutritional and medicinal values, products. J. Sci. Food Agric. 2013, 93, 2351-2361. [CrossRef]

17. Al-Farsi, M.A.; Lee, C.Y. Optimization of phenolics and dietary fibre extraction from date seeds. Food Chem. 2008, 108, 977-985. Available online: http://www.sciencedirect.com/science/article/pii/S0308814607012654 (accessed on 27 May 2020). [CrossRef]

18. Juhaimi, F.A.; Ghafoor, K.; Özcan, M.M. Physical and chemical properties, antioxidant activity, total phenol and mineral profile of seeds of seven different date fruit (Phoenix dactylifera L.) varieties. Int. J. Food Sci. Nutr. 2012, 63, 84-89. [CrossRef] [PubMed]

19. Chandrasekaran, M.; Bahkali, A.H. Valorization of date palm (Phoenix dactylifera) fruit processing by-products and wastes using bioprocess technology-Review. Saudi J. Biol. Sci. 2013, 20, 105-120. [CrossRef] [PubMed]

20. Tang, Z.-X.; Shi, L.-E.; Aleid, S.M. Date and their processing byproducts as substrates for bioactive compounds production. Braz. Arch. Biol. Technol. 2014, 57, 706-713. [CrossRef]

21. Ayad, A.A. Survival and Viability of Freeze/Spray-Dried Lactobacillus ssp. Grown in Date Palm (Phoenix dactylifera L.) Base Medium; North Carolina Agricultural and Technical State University: Greensboro, NC, USA, 2016.

22. Ayad, A.A.; El-Rab, D.G.; Shahbazi, A.; Worku, M.; Schimmel, K.; Ejimakor, G.; Zimmerman, T.; Ibrahim, S.A. Using Date Palm (Phoenix dactylifera L.) by-products to Cultivate Lactobacillus reuteri spp. J. Food Res. 2016, 5, 77. [CrossRef]

23. Nancib, N.; Nancib, A.; Boudjelal, A.; Benslimane, C.; Blanchard, F.; Boudrant, J. The effect of supplementation by different nitrogen sources on the production of lactic acid from date juice by Lactobacillus casei subsp. rhamnosus. Bioresour. Technol. 2001, 78, 149-153. [CrossRef]

24. Spinler, J.K.; Taweechotipatr, M.; Rognerud, C.L.; Ou, C.N.; Tumwasorn, S.; Versalovic, J. Human-derived probiotic Lactobacillus reuteri demonstrate antimicrobial activities targeting diverse enteric bacterial pathogens. Anaerobe 2008, 14, 166-171. [CrossRef]

25. Su, M.S.-W.; Oh, P.L.; Walter, J.; Gänzle, M.G. Intestinal origin of sourdough Lactobacillus reuteri isolates as revealed by phylogenetic, genetic, and physiological analysis. Appl. Environ. Microbiol. 2012, 78, 6777-6780. [CrossRef] [PubMed]

(C) 2020 by the authors. Licensee MDPI, Basel, Switzerland. This article is an open access article distributed under the terms and conditions of the Creative Commons Attribution (CC BY) license (http://creativecommons.org/licenses/by/4.0/). 